\title{
Accountancy en bedrijfseconomie
}

\author{
Een hechte relatie
}

Prof. L.C. van Zutphen

NIVRA 1895 - 1995. Een eeuw georganiseerd accountantsberoep in Nederland.

Een mijlpaal die ook de redactie van het MAB niet ongemerkt voorbij wil laten gian.

De feestelijkheden rond dit jubileum van de beroepsorganisatie van registeraccountants bereiken een hoogtepunt in de mainnd mei van dit jaar. Vandaar de alanbieding van dit speciale felicitatie-nummer van ons blad. dal zo nauw betrokken is geweest bij de ontwikkeling van het accountantsberoep in Nederland.

Voor zeer vele praktiserende accountants en accountancy-studenten was en is het MAB een onmisbare bron van informatie en sudie op de brede terreinen van de accountancy en de bedrijfseconomie. Twee disciplines die alleen in samenhang kunnen worden bestudeerd en beoefend. Het was juist deze opvatling en overtuiging die ook door de pioniers van de accountantsprofessie in Nederland werd uitgedragen.

In januari 1924 verscheen het eerste nummer van het Maandblad voor Accountancy en Bedrijfshuishoudkunde. De redactie bestond toen vrijwel uitsluitend uit accountants, waaronder ook nu nog bekende namen als R.A. Dijker. G.P.J. Hogeweg. Prof. Th. Limperg Jr. en H.R. Reder. Onder de rubriekredacteuren en vaste medewerkers treffen we E. van Dien. Abr. Mey, Dr. A. Sternheim, Dr. N.J. Polak en Prof. J.G. Ch. Volmer.

Bijna de gehele redactie was atkomstig van het Malandblad Accountancy, waarvan Th. Limperg

Prof. L.C. van Zutphen RA is hoogleraar Accountantscontrole aan de Vrije Universiteit te Amsterdam. Daarnaast is hij voorzitter van het Limperg Instituut en lid van de Orde van Organisatiekundigen en -Adviseurs. vrijwel sedert de oprichting in 1903 de hoofdredacteur was.

Dat zou zo blijven tot oktober 1923, in welke malud hij - na een conflict met de uitgever van het maandblad Accountancy, G. Delwel in Wassenaar - abrupt zijn redacteurschap beëindigde. Dat deze stap door de nieuwe redactie van Accountancy werd hetreurd mag wel blijken uit de openings- en slotzin opgenomen in de mededeling van dit feit aan de lezers van het blad: 'Le roi est mort. vive le roi!".

Al in een toelichting op de nieuw gekozen naam. Maandblad voor Accountancy en Bedrijfshuishoudkunde, stelt de nieuwe en nu collectieve redactie in januari 1924, dat het accountantsberoep hier te lande zich allengs ontwikkeld heeft in cen richting, 'welke aan den functie van den accountant in de maitschappij een andere en grootere beteekenis heeft gegeven, dan door de grondleggers der accountancy is gedacht. Die ontwikkeling heeft er toe geleid, dal de bedrijfshuishoudkunde. als deelwelenschap der economie, een der grondslagen is geworden voor studie en opleiding en de oplossing der bedrijlshoudkundige problemen een deel is geworden van de beroepstaak der accountants".

In hel oktobernummer van de jatargang 1924 van het MAB publiceert Limperg een principieel en doorwrocht artikel over 'De beteekenis der Bedrijfshuishoudkunde voor den Accountant'. Hij claimt overigens nadrukkelijk niet het recht dit voor de beroepsuitoefening zo belangrijke thema als eerste natar voren te hebben gebracht.

Daarvoor verwijst Limperg naiar $\mathrm{H}$. Sparrius die reeds in 1908 een artikel in het maandblad 
Accountancy publiceerde onder de titel 'Een nieuwe wetenschap?'

Hierin bepleit Sparrius voor het eerst het bestaansrecht van de bedrijfseconomie in ons land en wees daarbij tegelijkertijd op de grote betekenis van dit vak voor de accountant.

Waar Limperg c.s. de bedrijfseconomie en de accountancy als een verbonden stelsel van leerstukken beschouwden en toepasten. liggen deze tijden inmiddels ver achter ons. Het 'all in one' heeft via een explosie van specialismen en leeropdrachten geleid tot een veelheid van aandachtsgebieden als accountantscontrole, bestuurlijke informatieverzorging en administratieve organisatie, externe verslaggeving, management accounting, financiering, marketing, organisatie en management, EDP auditing enz.

En dit weerspiegelt zich uiteraard ook in de praktijk. Want in de produkten- en dienstenpakketten, die accountantskantoren in onze tijd aanbieden, ligt de zaak niet anders.

De accountant-generalist uit de tijd van Limperg zou niet meer in staat zijn in de soms zeer specialistische controle- en adviesbehoeften van de markt te voorzien.

Door middel van bijvoorbeeld branchespecialisaties en verregaande specialisatie op consultancygebied geeft het moderne accountantskantoor antwoord op de eisen die de markt stelt. Daarbij blijft de verbondenheid tussen accountancy en bedrijfseconomie ook nu nog als een van de belangrijke uitgangspunten gelden. Alle problemen van integratie en coördinatie ten spijt.

Ook in de vernieuwde postdoctorale accountantsopleidingen zal aan de geïntegreerde behandeling van bedrijfseconomische en accountancyvraagstukken veel aandacht moeten worden besteed.

$\mathrm{Er}$ is veel is veranderd voor de Nederlandse accountant in de afgelopen eeuw. Maar de hechte en vruchtbare relatie tussen accountancy en bedrijfseconomie is gebleven.

Ook in de toekomst zullen accountants hun controlerende en adviserende functies naar mijn overtuiging alleen doeltreffend kunnen vervullen als deze blijven stoelen op een moderne en brede bedrijfseconomische vorming.

Een korte blik op de inhoud van dit nummer, uiteraard vol met complimenten, felicitaties en wensen voor de toekomst aan het jubilerende Instituut.

$\mathrm{Na}$ een feestelijke column met ingebouwde moraal van ons redactielid Hans Blokdijk opent Prof. Dr. A.J. Bindenga RA de rij met een felicitatie namens de openbare accountants. Een gelukwens, die vergezeld gaat van een analyse van de huidige positie van het openbare accountantsberoep op de markt en in de maatschappij. Een analyse die uitmondt in een visie op de toekomst van de accountancy en de rol van het NIVRA daarin.

Dat het NIVRA zich heeft ontwikkeld tot een pluriforme beroepsorganisatie van registeraccountants mag blijken uit drie daaropvolgende artikelen geschreven door de voorzitters van de overlegorganen voor interne accountants, overheidsaccountancy en registeraccountants werkzaam in de financieel-administratieve sector.

Collega R.O.M. de Jaeger RA bespreekt de dynamiek van de internal audit functie in Nederland. In het bijzonder wordt aandacht besteed aan taakverschuivingen van financial naar internal audit-activiteiten en hun betekenis voor de organen van de vennootschap en het maatschappelijk verkeer.

De ontwikkelingen op het terrein van de overheidsaccountancy worden bespiegeld door A.W. van de Zand RA. De geschiedenis van de overheidsaccountancy wordt behandeld in relatie tot de betekenis van het NIVRA voor de overheidsaccountancy in de afgelopen eeuw.

Drs. G.H. Koolman RA geeft een korte terugblik op de ontstaansgeschiedenis van de FINAD, het overlegorgaan voor 'financieeladministratieve' functionarissen binnen het NIVRA. De meeste aandacht in zijn artikel gaat echter uit naar de toekomst van het Controllers Instituut, een stichting die onlangs door de FINAD en de Vereniging van Registercontrollers werd opgericht.

Drs. M.J.J.M. van Grootel RA beschrijft de wordingsgeschiedenis van de SRA, het samenwerkingsverband van de kleinere accountantskantoren in ons land.

Een ontwikkeling die zich vooral in de afgelopen vijf jaar heeft voltrokken.

De hechte relaties met het NIVRA blijven niet onbesproken. 
Mevrouw M.J.L. van Ool RA feliciteert het NIVRA namens de Kring van Vrouwelijke Registeraccountants. De groep vrouwelijke accountants makkt - na een trage start tot in de jaren tachtig - de laatste tijd een sterke groei door. Collega Van Ool schrijft met enthousiasme over het accountantsberoep en voert het pleit voor een beleid dat snel tot een belangrijker positie van de vrouw in het Nederlandse accountantsberoep zal leiden in het belang van de professie en de matschappij.

De geschiedenis van hel NIVRA als opleidingsinstituut wordt boeiend beschreven door J.C.H. Venema, voorzitter Algemeen Bestuur Onderwijs NIVRA opleiding. Een artikel over een van de hoofdactiviteiten van het Instituut met veel interessante details.

Prof. Drs. G.G.M. Bak tekent ontwikkelingslijnen in het kader van de universitaire accountantsopleiding. Ook in de sfeer van de universitaire accountantsopleidingen wordt de laatste tijd veel aandacht besteed aan alanpassing en herstructurering van het opleidingssysteem. Zijn pleidooi voor post-ervaringsonderwijs voor accountants kan veel stof tot nadenken geven.

Twee meer persoonlijke bijdragen ontbreken niet in dit nummer.
Prof. Dr. A.B. Frielink tekent de 'gezichten van het Instituut' zoals hij die in zijn vele functies en contacten met het NIVRA heeft meegemaakt en ervaren.

Zestig jaar omspannen deze herinneringen; oudere en jongere registeraccountants zullen er met een mix van herkenning,verbazing en een glimlach kennis van nemen.

Dr. mr. R.N.J. Kamerling RA beschrijft opkomst en ondergang van de NV Oliefabrieken Insulincle in het voormalige Nederlandsch Indië, uitmondend in een faillissement aan het begin van de jaren twintig. Analyse van een destijds opzienbarende deconfiture.

Ten slotte komt een onderzoeker aan het woord. Prof. Dr. A. van Witteloostuijn.

In woord en grafiek beschrijft en analyseert hij de groei van het accountantsberoep en de accountancymarkt in ons land. Een interessante kwantificering van de beroepsontwikkeling. die op zich weer de nodige vragen oproept.

Al met al een reeks artikelen geschreven door een brede range van auteurs, waarvan een ieder zich op zijn eigen wijze met het jubilerende NIVRA verbonden weet. 